\title{
Indicators of Inequality for Māori and Pacific People
}

\author{
LISA MARRIOTT AND DALICE SIM
}

\begin{abstract}
This study investigates a number of inequality indicators in New Zealand. The research examines the current gaps in the indicators between the European population, and Māori and Pacific people. The study also undertakes a comparison of the changes in the gaps over a period approximating 10 years for each of the indicators. A total of 21 indicators are investigated in this study, incorporating measures of health; knowledge and skills; employment; standards of living; cultural identity; and social connectedness.
\end{abstract}

The aim of this research is to assess the extent to which indicators suggest that the inequality gap is increasing or decreasing between European and Māori, and European and Pacific people in New Zealand. In general, all ethnic group measurements are moving in the same direction, that is, most ethnic groups are improving or not improving for a specific measure. However, increases are visible in gaps for the majority of the indicators examined in this article, that is, the indicators suggest greater inequality has resulted over the 10-year period for both Māori and Pacific people.

Of the 21 indicators assessed in this study, nine (43 per cent) show improvements in the form of a decreasing gap between European and Māori, although not all of these improvements are significant. Less positive results are visible in 11 indicators (52 per cent), which produce increasing gaps between European and Māori. One indicator is largely unchanged. Not all indicators are available for Pacific people, but of the indicators measured, six (35 per cent) showed an improvement in the form of closing gaps between the European population and Pacific people. Again not all of the decreases in gaps are significant. Worsening differences were found in 10 (59 per cent) of the indicators measuring inequality between the European population and Pacific people. Similarly to the Māori population, one indicator remained unchanged.

The measures that are most likely to impact on overall outcomes are those where performance is weak: employment/unemployment and income. Redistribution through the tax and transfer system is effective, but primarily for those who are in the workforce. Thus, focusing on improving the skills and education of those who perform least well in the knowledge and skills indicators will enhance both employment opportunities and earning capacity for those "least equal" in society, and potentially assist with improving inequality in New Zealand. Furthermore, based on current trends, a focus on addressing inequality via the tax system may now be warranted. The absence of inheritance taxes or a comprehensive capital gains tax limits potential opportunities to engage in greater redistribution.

\section{Introduction}

Dorling suggests that growing income and wealth inequality is the greatest social threat of our time. ${ }^{1}$ Most OECD countries have seen an increase in the gaps between the wealthy and the less-wealthy in recent times. ${ }^{2}$ Addressing inequality is important for multiple reasons: it assists with creating a fair society where individuals have equality of opportunity by identifying specific areas where improvement is required; it is important for economic growth; it is important for social cohesion; and inequality generates fiscal costs on the wider community, such as through increased crime and health expenditure. ${ }^{3}$ Perhaps the problem is best captured 
by the OECD: "greater inequality raises economic, political and ethical challenges as it risks leaving a growing number of people behind in an ever-changing economy." 4

The patterns of inequality in New Zealand are well-established. The wealthiest one per cent of New Zealanders own three times as much as the poorest 50 per cent, with the wealthiest ten per cent owning half of the country's total wealth. ${ }^{5}$ The lowest income earners in New Zealand have seen little in the way of income increases over the past 30 years. ${ }^{6}$ Moreover, when housing costs are taken into account, the lowest income households have less money to spend than 30 years ago. ${ }^{7}$

Regardless of whether income or wealth are used as measures of inequality, New Zealand scores around the average of OECD countries, with similar levels of inequality to Australia, Japan and Canada. ${ }^{8}$ In terms of how this is reflected in society, the top 10 per cent in New Zealand earn 8.6 times the income of the bottom 10 per cent, once tax and transfers are taken into account. ${ }^{9}$ Recent polls in New Zealand suggest that poverty, the gap between rich and poor, and the imbalance in wealth in New Zealand are becoming of increasing concern to New Zealanders. ${ }^{10}$

Inequality captures the distribution of resources across society. While this is an important measure, it is also important to investigate differences in distributions among different ethnic groups. If inequality is equally represented among different ethnic groups, we would expect to find a similar proportion of each ethnic group under each measure. To the extent that a different ethnic groups has a different representation in a social indicator, this suggests greater or lesser inequality among that ethnic group. This study focuses on the differences in 21 social indicators that capture a range of inequality measures across three ethnic groups in New Zealand: Europeans, Māori and Pacific people. The aim of the study is to report on differences found among these three ethnic groups for a range of inequality measures.

In December 2003, the Strategic Social Policy Group of the Ministry of Social Development released a report titled Social Indicators for the Pacific and Māori Populations. ${ }^{11}$ A follow up report was produced in the following year: Reducing Inequalities Indicators for Māori and Pacific Peoples. ${ }^{12}$ These reports outlined a number of indicators of inequality in a range of categories: health; knowledge and skills; paid work; economic standard of living; cultural identity; safety; and social connectedness. The reports provided the direction of movement of each indicator, i.e. improving, worsening or no clear trend. Of the 27 indicators in the 2003 report, six showed improvements for Pacific people and 13 showed improvements for Māori populations. However, a number of indicators produced no result, as information was not available, or no clear trend was evident. For Māori populations, none of the indicators produced worsening trends, while one produced a worsening trend for Pacific people.

It is 10 years since these reports were released by the Ministry of Social Development. This study provides a follow up to the report, to review progress on a range of inequality measures in New Zealand over the past decade. Numerous policies were introduced subsequent to the 2003 report with the aim of measuring and improving identified inequalities. ${ }^{13}$ The initial reports provided absolute and relative measures of improvement against previous measures for the same population and a comparison population, usually Europeans. This research adopts the same approach.

This study commences with a review of some of the recent literature on inequality. This is followed in section three with a discussion of the methodology and data sources used in this study. Section four outlines the data and the data analysis, while section five provides a discussion of the findings. The article concludes in section six.

\section{Background}

The issues relating to inequality have become well known over the past decade. This may, at least in part, be attributed to works such as The Spirit Level: Why Equality is Betterfor Everyone, 
Capital in the Twenty-First Century, The Price of Inequality and Inequality and the 1\%. ${ }^{14}$ Studies such as these have raised the profile of inequality and communicated the potential wideranging effects from inequality; not just among those who are among the lower deciles in society. Particularly noticeable in more recent times is the growing social cohesion among protestors against increases in inequality, as "the vast majority of people in a majority of rich countries are now suffering as a result of growing inequalities." 15 A further issue with inequality is the suggestion that it has a long-term effect, with income inequality experienced early in life, resulting in reduced social mobility later in life. ${ }^{16}$

There are multiple other reasons why equality is desirable. Inequality limits the opportunities for people to maximise their potential contribution to the economy and to society. ${ }^{17}$ The economic loss is explained by Nana as "a very real economic loss incurred by the existence of unemployed, under-employed, untrained, disenchanted, disconnected, disenfranchised and, indeed, disruptive resources." ${ }^{18}$ Nana expands on the inefficiency generated by inequality by highlighting the additional resources that are diverted from wealthenhancing activities and allocated to "picking up the pieces." 19 The impacts of the inefficiency generated from inequality are felt across all of society, including businesses who have a less skilled workforce; higher tax rates to fund the costs of inequality; and the lost potential economic growth from under-utilisation of human resources.

Multiple studies link poor health measures to income inequality. For example, research suggests that national mortality rates are lowest in countries that have smaller income differences ${ }^{20}$ and income inequality "is accompanied by many differences in conditions of life at the individual and population levels, which may adversely influence health." 21 Mackenbach, a frequent researcher on socio-economic inequalities and health outcomes, captures the essence of the problem, noting "consistent evidence throughout the world that people at a socioeconomic disadvantage suffer a heavier burden of illness and have higher mortality rates than their better-off counterparts." 22 Perhaps the point is captured most succinctly by Dorling, who writes "all sections of society live longer in countries that are more egalitarian." 23 Of particular importance is the recognition that health inequalities are avoidable and may be influenced by policy interventions. ${ }^{24}$

As noted above, inequality does not only impact on individuals. Research suggests that all of society is better off where people are more equal. While inequality has been shown to produce negative outcomes at the individual level, lower levels of inequality have been shown to produce positive outcomes at a national level. For example, Ostry, Berg and Tsangarides show that lower net inequality is robustly correlated with faster and more durable economic growth. ${ }^{25}$ This was recognised by the New Zealand Cabinet Social Development Committee, with the observation that prosperity depends on improving the productivity of all citizens and that providing greater opportunities for everyone will allow greater participation in, and contribution to, society. ${ }^{26}$

While inequality is not solely related to income inequality, the income inequality measure is one of the most common measures used as a determinant of standard of living. As noted by the OECD, high income inequalities "typically imply a waste of human resources, in the form of a large share of the population out of work or trapped in low-paid and low-skilled jobs."27 However, one of the key difficulties with assessing income inequality is the difficulty in obtaining measures that effectively capture differences in incomes. ${ }^{28}$ The most common measure of income inequality is the Gini coefficient. The Gini coefficient ranges from zero to one, with higher numbers indicating higher levels of inequality. The Gini coefficient is based on a comparison of cumulative proportions of the population against cumulative proportions of income received. ${ }^{29}$ Thus, perfect equality is achieved when the Gini coefficient value is zero (that is, where the bottom 10 per cent of the population receive 10 per cent of the income, the bottom 20 per cent of the population receive 20 per cent of the income, etc.). ${ }^{30}$ Perfect inequality 
exists when the Gini coefficient value is one, as this represents a situation where all income goes to one person. Despite the widespread use of the Gini coefficient as an indicator of income inequality, it has limitations, including that it is a single indicator that does not express the value judgements underlying it. ${ }^{31}$

While there has been considerable variation in income inequality among OECD countries as measured by the Gini coefficient in recent decades, New Zealand has shown one of the strongest increases in income inequality over the period from the mid-1980s to the mid-2000s. ${ }^{32}$ However, over the time period investigated in this study, the Gini coefficient has been largely unchanged. ${ }^{33}$ The most recent Gini coefficient for New Zealand is 2011, where it was 0.32. ${ }^{34}$ This is the same as Australia and the OECD average. However, it is higher than Denmark (0.25), Finland (0.27), Norway (0.25) and Sweden (0.27). ${ }^{35}$

The OECD raise a number of factors that have influenced changes in both income inequality and poverty over time. The primary factors that are visible among OECD countries include:

- Changes in the structure of the population, including the increase in the number of single-person households;

- Earnings becoming more unequal. This is driven by globalisation, skill-biased technical change and labour market institutions;

- Falling employment rates among people who are less educated;

- Unequal distribution of capital income and self-employment income. ${ }^{36}$

Historically, on average, general outcomes for Māori and Pacific people have been less positive than those for the European population. This point is highlighted by Rashbrooke who writes: "a shocking statistic for New Zealand is the disproportionate number of Māori and Pacific people living below the poverty line." ${ }^{37}$ Perry reports that Māori and Pacific ethnic groups typically have poverty rates that are around double those of the European/Pakeha ethnic group, regardless of the measure used. ${ }^{38}$ Using the measure of less than 60 per cent of the median income, 23 per cent of Māori, 22 per cent of Pacific people, and 11 per cent of European/Pakeha people had household incomes below this threshold. ${ }^{39}$ While poverty is a different issue to inequality, to the extent that greater inequalities exist among certain ethnic groups, the result is higher levels of poverty among these ethnic groups.

Other examples of reported gaps in performance (at 2013) include:

- A secondary school retention rate (to age 17) for Māori students of $67.9 \%(82.5 \%$ for all students) ${ }^{40}$

- School leavers achieving a university entrance standard for Māori Youth of 26.8\% (49\% for all school leavers) $;^{41}$

- A higher rate of Māori youth (15-24 years of age) not in education or employment or training at $23.2 \%$ (19.8\% for Pacific youth and $11.4 \%$ for European youth). ${ }^{42}$

At the time of the Ministry of Social Development reports that this study replicates a number of policy initiatives were proposed to assist with addressing inequality. ${ }^{43}$ These policies included:

- Ensuring a robust programme of early intervention for at-risk children and families;

- Addressing the income needs of children in low-income families through implementation of the Working for Families programme;

- Continuing the focus on the health needs of families/whänau through improving access to health services;

- Increasing participation in early childhood education where participation is low; 
- Improving participation and achievement among young people who are at risk of leaving school with few qualifications;

- Improving access to education, training and employment for economically inactive young people;

- Addressing the barriers to employment;

- Tackling risk factors of poor health and improving access to services for those currently at risk of poor health outcomes. ${ }^{44}$

A number of these policies were implemented at or around the time of the Ministry of Social Development reports, or are ongoing at the present time, such as addressing the barriers to employment and tackling risk factors relating to health. However, the focus that was visible a decade ago on specifically addressing the drivers of inequality appears to have diminished, with the last six-monthly report on reducing inequalities produced for the period July to December $2003 .{ }^{45}$ At the time of the last six-monthly report, 109 initiatives were reported on by 12 government agencies. Of the 109 initiatives, 49 were from the Ministry of Education, 14 were from the Ministry of Health and 10 were from the Ministry of Housing.

\section{Methodology}

This study is a comparative study of the European, Māori, and Pacific people in New Zealand using a number of inequality indicators. The study replicates work undertaken by the Ministry of Social Development in New Zealand in 2003 and 2004, where two reports were produced outlining a number of indicators intended to measure inequality among Māori and Pacific people. This research reviews the same indicators after a period as close as possible to 10 years. Not all of the measures reported in the initial studies have been replicated here. For some indicators, data is not available, or due to measurement changes over the 10 -year period, it is not comparable over time.

The following section outlines the data and statistical methods used to assess the indicators outlined in section four. We also adopt the same presentation structure as the original Ministry of Social Development reports that this study replicates. We acknowledge that this is not the usual presentation style, where typically a causal approach would be adopted (e.g. unemployment and income measures prior to health measures).

\section{Data}

The four primary ethnic groups in New Zealand are European, Māori, Pacific people and Asian. This study investigates European, Māori and Pacific people. Ethnicity is "the ethnic group or groups that people identify with or feel they belong to." 46 The measure is based on self-perception and it is possible to belong to more than one ethnic group.

Over the time period covered by this study, Statistics New Zealand changed the way it recorded the ethnicity of individuals in its reports. Before 2006, ethnicity was prioritised, so that each person was allocated to only one ethnicity ("prioritised ethnicity"). The priority was: Māori first, then Pacific, then other groups, and finally Europeans. Thus, the only people in the "European" group were those who did not indicate any other ethnicity, while any who indicated Māori were allocated to the Māori group. After 2006 in census data, and other official statistics, a person identifying with more than one ethnic group is counted once in each group ("total ethnicity"). This difference of definition affects Tables 8, 10-13, 15 and 16. For both timepoints, the Māori group are defined the same - anyone who said they were Māori is counted as Māori. For the Pacific group, those in the earlier date are those who are Pacific and not Māori, while at the later time-point, anyone who said they were of Pacific origin is counted in the Pacific group. For the European group, those at the earlier time-point are coded as European if 
they checked only "European" for their ethnicity, while those at the later time-point included anyone who checked that they were European. As a result of this change in reporting, the expectation would be that the groups would be more alike at the later time-point, since they contain some of the same people. Nevertheless, the difference is unlikely to be great.

As our primary research focus is on inequality differences between Māori and Pacific people, we have not included Asian people in this analysis. Asian people are the third most common ethnic grouping in New Zealand, with 12 per cent of the population identifying with at least one Asian ethnic group in the 2013 census. Of the four primary ethnic groups, the Asian group is increasing at the fastest pace, with a 33 per cent increase since the previous census in $2006 .{ }^{47}$ Of relevance to this study is that Asian people are often proportionately more highly represented in positive indicators. Thus, this is changing outcomes for the other ethnic groups, which is an important consideration in interpreting some of the indicators discussed in this study.

There are demographic differences between the three populations investigated in this study. In the most recent New Zealand census, 74 per cent of people identified with at least one European ethnicity; 15 per cent identified as Māori; and 7 per cent identified as Pacific people. $^{48}$ The median age is 41 years for those identifying as European; 23.9 years for those identifying as Māori; and 22.1 years for those identifying as Pacific people. ${ }^{49}$ Thus, the population groups for Māori and Pacific people are younger than the European group.

Each of the indicators is presented in a table showing data in two time periods, with as close as possible to a 10-year gap. Each of the tables also shows the absolute and relative change over the two time periods shown, as well as the gaps between the European population, and Māori and Pacific people over the specified periods. ${ }^{50}$ In some cases a negative difference indicates that the gaps have closed, i.e., there is some degree of "catching-up" in the indicator; while in other cases a negative difference indicates that the gaps have widened. For the purposes of clarity, we have also explicitly stated whether the data shows a closing or increasing gap.

\section{Statistical Methods}

Data for this study come from a variety of public sources and institutions, including Statistics New Zealand, the Ministry of Education and the Ministry of Social Development. For some data (e.g. statistics on numbers enrolled in schools as recorded by the Ministry of Education), the numbers presented come from a complete count or census of individuals. In such cases, the figures have been used as percentages without error, and no statistical analysis has been done.

Other estimates of percentages come from survey data. In these cases, proportions between ethnic groups have been compared using the chi-squared $\left(\chi^{2}\right)$ statistic to test one variable at a time, or logistic regression, to examine the effect of time, ethnicity, and their interaction. In Tables 13 and 14, means were reported together with confidence limits and/ or sampling errors, which allowed us to calculate standard deviations, and use the $\mathrm{Z}$ test to compare between groups.

\section{Indicators of Inequality}

This section is comprised of six sub-sections. Each sub-section addresses a different group of inequality indicators. As outlined above, the indicators are those used in earlier studies by the Ministry of Social Development. The measures are from the following categories: health; knowledge and skills; paid work; economic standard of living; cultural identity; and social connectedness. 


\section{Health}

Studies indicate that greater inequality, typically measured by income, results in poorer average health. ${ }^{51}$ The extent of inequalities in health in New Zealand was described as "unacceptable" by the Deputy Director-General of Public Health in 2003. ${ }^{52}$ Research typically shows health outcomes for Māori people as poorer than other population groupings. For example, research by Bramley, et al. reports on differences in health outcomes between the numerically dominant population group and the indigenous population in the United States (Europeans and American Indians/Alaska Natives) and New Zealand (Europeans and Māori). ${ }^{53}$ In both countries poorer health outcomes are reported among the minority populations. However, in almost every health status indicator assessed in the study, disparities were more pronounced for Māori people than for American Indians/Alaska Natives, despite significant gains in the health measures investigated over recent decades. Similarly, Ajwani et al. also find that indigenous people tend to have poorer health outcomes when compared to the majority population. ${ }^{54}$

This study reports on five measures of health over the following sub-sections: life expectancy at birth; prevalence of cigarette smoking; obesity; suicide rates; and infant mortality.

\section{Life Expectancy at Birth}

Table 1 shows life expectancy for Māori and non-Māori, males and females, over a 10-year period. This data is not available for Pacific people.

Table 1: Life Expectancy at Birth ${ }^{55}$

\begin{tabular}{|l|l|l|l|l|}
\hline & $\mathbf{2 0 0 0 - 0 2}$ & $\mathbf{2 0 1 0 - 2 0 1 2}$ & $\begin{array}{l}\text { Absolute Change } \\
\mathbf{( 2 0 1 0 - 1 2} \mathbf{- 2 0 0 0 -} \\
\mathbf{2 0 0 2})\end{array}$ & $\begin{array}{l}\text { Relative } \\
\text { Change }\end{array}$ \\
\hline Non-Māori (male) & 77.2 years & 80.2 years & +3.0 years & $3.9 \%$ \\
\hline Non-Māori (female) & 81.9 years & 83.7 years & +1.8 years & $2.2 \%$ \\
\hline Māori (male) & 69 years & 72.8 years & +3.8 years & $5.5 \%$ \\
\hline Māori (female) & 73.2 years & 76.5 years & +3.3 years & $4.5 \%$ \\
\hline $\begin{array}{l}\text { Gap (Non-Māori males } \\
\text { minus Māori males) }\end{array}$ & 8.2 years & 7.4 years & $\begin{array}{l}-0.8 \text { years } \\
\text { (closing gap) }\end{array}$ & $-9.8 \%$ \\
\hline $\begin{array}{l}\text { Gap (Non-Māori females } \\
\text { minus Māori females) }\end{array}$ & 8.7 years & 7.2 years & $\begin{array}{l}-1.5 \text { years } \\
\text { (closing gap) }\end{array}$ & $-17.2 \%$ \\
\hline
\end{tabular}

Data Source: Statistics New Zealand

Table 1 shows improvements in life expectancy for all groups over the 10 year period investigated. Non-Māori males' life expectancy has increased from 77.2 years to 80.2 years, while non- Māori females' life expectancy has increased from 81.9 years to 83.7 years. Māori males' life expectancy has increased from 69 years to 72.8 years, while Māori females' life expectancy has increased from 73.2 years to 76.5 years. The changes show a small reduction in the gaps of life expectancy for both Māori males and females, but the gaps remain high at over seven years for both groups. These gaps are, at least in part, attributable to different rates of diabetes and cigarette smoking, as well as socio-economic factors. ${ }^{56}$

\section{Cigarette Smoking}

Smoking is an important social indicator due to its impact on health outcomes. Blakely, Fawcett, Hunt and Wilson demonstrate a link between tobacco smoking and ethnic inequalities in mortality in New Zealand; ${ }^{57}$ while Barnett, Pearce and Moon find that levels of social inequality between Māori and European people have an independent effect on Māori smoking rates. ${ }^{58}$ Table 2 outlines the prevalence of cigarette smoking for Europeans, Māori and Pacific 
people. The table shows that there has been a general decline in the proportion of people who smoke cigarettes across all ethnic groups. This indicator assesses a seven-year gap in order to use the most accurate data for this measure (the New Zealand census).

Table 2: Prevalence of Cigarette Smoking ${ }^{59}$

\begin{tabular}{|l|l|l|l|l|}
\hline & $\mathbf{2 0 0 6}$ & $\mathbf{2 0 1 3}$ & $\begin{array}{l}\text { Absolute Change } \\
(\mathbf{2 0 1 1 - 1 2}-\mathbf{2 0 0 6 - 0 7})\end{array}$ & $\begin{array}{l}\text { Relative } \\
\text { Change }\end{array}$ \\
\hline European & $18.5 \%$ & $13.4 \%$ & $-5.1 \%$ & $-27.6 \%$ \\
\hline Māori & $39.5 \%$ & $30.9 \%$ & $-8.6 \%$ & $-21.8 \%$ \\
\hline Pacific people & $27.9 \%$ & $21.6 \%$ & $-6.3 \%$ & $-22.6 \%$ \\
\hline Gap: European - Māori & $-21 \%$ & $-17.5 \%$ & $-3.5 \%$ (decreasing gap) & $-16.7 \%$ \\
\hline Gap: European - Pacific people & $-9.4 \%$ & $-8.2 \%$ & $-1.2 \%$ (decreasing gap) & $-12.8 \%$ \\
\hline
\end{tabular}

Data Source: Statistics New Zealand Census of Population and Dwellings

Differences in the prevalence of smoking are visible in the three ethnic groups investigated. In 2013, 13.4 per cent of Europeans identified as cigarette smokers, while 30.9 per cent and 21.6 per cent of the Māori population and Pacific people, respectively, identified as cigarette smokers. The gap between Māori and European smokers, and the gap between Pacific people and European smokers, has decreased over the seven-year period shown.

The initial Ministry of Social Development report, that this study replicates, observed that while there were declines in cigarette smoking in the 1980s the decline had slowed in more recent years. ${ }^{60}$ The data outlined above shows that the declining trend remains visible. Moreover, the declining trend in cigarette smoking is forecast to continue as higher taxes are imposed on cigarettes.

\section{Obesity}

Table 3 outlines obesity among Europeans, Māori and Pacific people. These figures have been age standardised to control for differences in the age structures of the population. Table 3 shows that, on average, all ethnic groups have increasing proportions of people who are overweight or obese. The group that has the highest increase is Māori, who have increased from $65.3 \%$ of people overweight or obese, to $76.3 \%$.

Table 3: Proportions of People who are Overweight or Obese (aged 15 years and over) ${ }^{61}$

\begin{tabular}{|l|l|l|l|l|}
\hline & $\mathbf{2 0 0 2 - 0 3}$ & $\mathbf{2 0 1 1 - 1 2}$ & $\begin{array}{l}\text { Absolute Change } \\
\mathbf{2 0 1 1 - 1 2}-\mathbf{2 0 0 2 - 0 3}\end{array}$ & $\begin{array}{l}\text { Relative } \\
\text { Change }\end{array}$ \\
\hline European & $53.7 \%$ & $60.8 \%$ & $+7.1 \%$ & $13.2 \%$ \\
\hline Māori & $65.3 \%$ & $76.3 \%$ & $+11 \%$ & $16.8 \%$ \\
\hline Pacific people & $79.6 \%$ & $87.8 \%$ & $+8.2 \%$ & $10.3 \%$ \\
\hline Gap: European - Māori & $-11.6 \%$ & $-15.5 \%$ & $\begin{array}{l}-3.9 \% \text { (increasing } \\
\text { gap) }\end{array}$ & $33.6 \%$ \\
\hline Gap: European - Pacific people & $-25.9 \%$ & $-27 \%$ & $\begin{array}{l}-1.1 \% \text { (increasing } \\
\text { gap) }\end{array}$ & $4.2 \%$ \\
\hline
\end{tabular}

Data Source: New Zealand Health Survey 
The gaps in obesity between Māori and the general population, and Pacific people and the general population, both show increases over the time period investigated. The figures also show differences in obesity among the ethnic groups, with Māori people in 2011-12 showing a gap of 15.5 percentage points when compared to the European population. This gap is considerably larger for Pacific people at 27 percentage points. The relative gap with the European population has increased 33.6 per cent for Māori and 4.2 per cent for Pacific people.

The normal $(Z)$ statistic was used to compare binomial proportions between years and ethnic groups. All ethnic groups had a statistically significant increase in age standardised prevalence between 2002-03 and 2011-12 ( $\mathrm{p}<.0005)$, except for Pacific people, where the difference between years was significant at the $\mathrm{p}=.0036$ level. In addition, each ethnic group was significantly different from the other two in both 2002-03 and 2011-12 ( $\mathrm{p}<.00005)$.

\section{Age-Standardised Suicide Rates}

The age-standardised suicide indicator measures deaths by suicide per 100,000 people. These figures for 2000 and 2010 are shown in Table 4. It is noted that relative to the size of the populations, deaths by suicide are small and therefore significant fluctuations may occur yearon-year. The analysis in this study also investigated the previous three years for variance, which produced similar results to that shown in Table 4. Figures for Pacific people are not available for this indicator.

Table 4: Age-Standardised Suicide Rates for Māori and Non-Māori ${ }^{62}$

\begin{tabular}{|l|l|l|l|l|}
\hline & $\mathbf{2 0 0 0}$ & $\mathbf{2 0 1 0}$ & $\begin{array}{l}\text { Absolute Change } \\
(\mathbf{2 0 1 0 - 2 0 0 0 )}\end{array}$ & $\begin{array}{l}\text { Relative } \\
\text { Change }\end{array}$ \\
\hline Non-Māori (male) & 18.8 & 15.4 & -3.4 & $-18.1 \%$ \\
\hline Non-Māori (female) & 4.2 & 5.7 & +1.5 & $35.7 \%$ \\
\hline Māori (male) & 25.5 & 23.9 & -1.6 & $-6.3 \%$ \\
\hline Māori (female) & 3.8 & 8.8 & +5.0 & $131.6 \%$ \\
\hline Gap: Non-Māori male - Māori male & -6.7 & -8.5 & -1.8 (increasing gap) & $26.9 \%$ \\
\hline $\begin{array}{l}\text { Gap: Non-Māori female - Māori } \\
\text { female }\end{array}$ & 0.4 & -3.1 & -3.5 (increasing gap) & $-875.0 \%$ \\
\hline
\end{tabular}

Data Source: Ministry of Health

The male Māori suicide rate is higher than the male non-Māori suicide rate with a rate of 25.5 and 23.9 suicides per 100,000 of population in 2000 and 2010, respectively. This compares to 18.8 and 15.4 suicides per 100,000 of population in 2000 and 2010 for non-Māori males. The female Māori suicide rate increased from 3.8 in 2000 to 8.8 suicides per 100,000 between 2000 and 2010, while non-Māori females increased from 4.2 to 5.7. The general trend for male suicide has been downward, while the trend for female suicide has been increasing, although more so for Māori females than non-Māori females. However, female suicide rates remain lower than males. The gap in suicide rates has increased between the two groups over the 10year period investigated: Māori male suicides have increased by 1.8 per 100,000 of population (26.9 per cent) while Māori female suicides have increased by 3.5 per 100,000 of population.

\section{Infant Mortality Rates}

The infant mortality indicator is measured by infant mortality per 1,000 live births. Infant mortality captures deaths of infants aged less than one year old. Table 5 shows infant mortality rates in 2000 and 2010. The comparison population is to non-Māori, non-Pacific for this indicator. 
Table 5: Infant Mortality Rates (per 1,000 live births) ${ }^{63}$

\begin{tabular}{|l|l|l|l|l|}
\hline & $\mathbf{2 0 0 0}$ & $\mathbf{2 0 1 0}$ & $\begin{array}{l}\text { Absolute } \\
\text { Change (2010- } \\
\text { 2000) }\end{array}$ & $\begin{array}{l}\text { Relative } \\
\text { Change }\end{array}$ \\
\hline Non-Māori; Non-Pacific & 6.3 & 5.5 & -0.8 & $-12.7 \%$ \\
\hline Māori & 8.5 & 7.0 & -1.5 & $-17.6 \%$ \\
\hline Pacific people & 10.2 & 8 & -2.2 & $-21.6 \%$ \\
\hline Gap: Non-Māori; Non-Pacific - Māori & -2.2 & -1.5 & $\begin{array}{l}+0.7 \text { (closing } \\
\text { gap) }\end{array}$ & $-31.8 \%$ \\
\hline $\begin{array}{l}\text { Gap: Non-Māori; Non-Pacific - Pacific } \\
\text { people }\end{array}$ & -3.9 & -2.5 & $\begin{array}{l}+1.4(\text { closing } \\
\text { gap) }\end{array}$ & $-35.9 \%$ \\
\hline
\end{tabular}

Data Source: Ministry of Health

All ethnic groups show improvements in infant mortality rates. However, the greatest improvements are in the Māori and Pacific people groups. While the rates for Māori and Pacific people in 2010 are still higher than the non-Māori; non-Pacific population, the gap is less pronounced than 10 years earlier, with both Māori and Pacific people showing relative improvements in infant mortality rates of over 30 per cent.

\section{Knowledge and Skills}

Enhancing knowledge and skills provides individuals with greater options in life. Education is one of the most well-known keys to success. ${ }^{64}$ It is generally accepted that educational achievement is linked with multiple positive outcomes: higher incomes, greater employment opportunities and positive health associations. Education has been linked to higher productivity and economic growth, which in turn can lead to improved standards of living. Moreover, possessing knowledge and skills can enhance peoples' sense of self-worth, security and belonging. ${ }^{65}$ This section provides data on four measures of knowledge and skills: participation in early childhood education; school leaver qualifications; the proportion of the population with a tertiary qualification; and tertiary participation rates.

\section{Participation in Early Childhood Education}

The data in Table 6 shows prior participation in early childhood education by Europeans, Māori and Pacific people in 2000 and 2012. This measure captures the proportion of children who have had early childhood education prior to starting school in the year shown.

Table 6: Participation in Early Childhood Education ${ }^{66}$

\begin{tabular}{|l|l|l|l|l|}
\hline & $\mathbf{2 0 0 0}$ & $\mathbf{2 0 1 2}$ & $\begin{array}{l}\text { Absolute Change } \\
(\mathbf{2 0 1 2 - 2 0 0 0 )}\end{array}$ & $\begin{array}{l}\text { Relative } \\
\text { Change }\end{array}$ \\
\hline European & $94.2 \%$ & $98 \%$ & $+3.8 \%$ & $4.0 \%$ \\
\hline Māori & $83.1 \%$ & $90.9 \%$ & $+7.8 \%$ & $9.4 \%$ \\
\hline Pacific people & $75.8 \%$ & $86.7 \%$ & $+10.9 \%$ & $14.4 \%$ \\
\hline Gap: European - Māori & $11.1 \%$ & $7.1 \%$ & $-4.0 \%$ (closing gap) & $-36.0 \%$ \\
\hline Gap: European - Pacific people & $18.4 \%$ & $11.3 \%$ & $-7.1 \%$ (closing gap) & $-38.6 \%$ \\
\hline
\end{tabular}

Data Source: Ministry of Education

Table 6 shows that there have been increases in early childhood education for all ethnic groups. The European population increased from 94.2 per cent to 98 per cent (four per cent); the Māori population increased from 83.1 to 90.9 per cent (9.4 per cent); and the Pacific 
population increased from 75.8 to 86.7 per cent (14.4 per cent). Both the Māori and Pacific people indicators showed decreases of over 30 per cent in the gap between early childhood education of European and Māori, and European and Pacific people.

\section{School Leavers with a Qualification of NCEA Level 2 or Equivalent}

Educational achievement is an important indicator of knowledge and skills in society. Moreover, success at secondary school can influence options to transition into higher education and the labour market. The following three indicators all relate to qualifications gained and participation in higher education. Table 7 shows school leavers holding the minimum qualification of National Certificate of Educational Achievement (NCEA) Level 2 or higher. NCEA is the primary secondary school qualification in New Zealand. It comprises three levels, typically undertaken in the final three years of secondary education.

Table 7: School Leavers with a Minimum of NCEA Level 2 or Equivalent ${ }^{67}$

\begin{tabular}{|l|l|l|l|l|}
\hline & $\mathbf{2 0 0 1}$ & $\mathbf{2 0 1 2}$ & $\begin{array}{l}\text { Absolute Change } \\
(\mathbf{2 0 1 2 - 2 0 0 1})\end{array}$ & $\begin{array}{l}\text { Relative } \\
\text { Change }\end{array}$ \\
\hline European & $68.5 \%$ & $82.1 \%$ & $+13.6 \%$ & $19.9 \%$ \\
\hline Māori & $40.6 \%$ & $60.9 \%$ & $+20.3 \%$ & $50.0 \%$ \\
\hline Pacific people & $54.7 \%$ & $68.1 \%$ & $+13.4 \%$ & $24.5 \%$ \\
\hline Gap: European and Māori & $27.9 \%$ & $21.2 \%$ & $-6.7 \%$ (closing gap) & $-24.0 \%$ \\
\hline Gap: European and Pacific people & $13.8 \%$ & $14.0 \%$ & $+0.2 \%$ (increasing gap) & $1.4 \%$ \\
\hline
\end{tabular}

Data Source: Ministry of Education

Table 7 shows improvements in educational achievement among all groups. The largest improvement is among the Māori students, with a 20.3 percentage point change ( 50 per cent) over the 11 year period shown. Pacific people and European school leavers both showed close to a 13.5 percentage point improvement in absolute terms (19.9 per cent for European and 24.5 per cent for Pacific people, in relative terms). There was a large difference in attaining educational achievements between the Māori and European students in 2001 at nearly 28 percentage points. While this has improved in 2012, a large gap of 21.2 percentage points remains. Moreover, the 13.8 percentage point gap in school leaver attainment among European and Pacific people has not improved and instead shows a small increase of 1.4 per cent.

\section{Proportion of the Population with a Bachelor's degree or higher}

Table 8 shows the proportion of the European, Māori, and Pacific people aged 15 years and over holding a Bachelor's degree or above as their highest qualification. This measure captures people holding bachelor's degrees and other post-graduate qualifications. As census data is used for this measure, a 12-year time period is presented. 
Table 8: Proportion of the Population with a Bachelor's Degree or Above ${ }^{68}$

\begin{tabular}{|l|l|l|l|l|}
\hline & $\mathbf{2 0 0 1}$ & $\mathbf{2 0 1 3}$ & $\begin{array}{l}\text { Absolute Change (2013- } \\
\mathbf{2 0 0 1}\end{array}$ & $\begin{array}{l}\text { Relative } \\
\text { Change }\end{array}$ \\
\hline European & $10.8 \%$ & $18.6 \%$ & $+7.8 \%$ & $72.2 \%$ \\
\hline Māori & $4.0 \%$ & $9.1 \%$ & $+5.1 \%$ & $127.5 \%$ \\
\hline Pacific people & $3.2 \%$ & $7.1 \%$ & $+3.9 \%$ & $121.9 \%$ \\
\hline Gap: European - Māori & $6.8 \%$ & $9.5 \%$ & $+2.7 \%$ (increasing gap) & $39.7 \%$ \\
\hline Gap: European - Pacific people & $7.6 \%$ & $11.5 \%$ & $+3.9 \%$ (increasing gap) & $51.3 \%$ \\
\hline
\end{tabular}

Data Source: Statistics New Zealand Census of Population and Dwellings

Table 8 shows that while proportions of the population holding Bachelor degrees or above have increased for all ethnic groups, the gaps between the European population and Māori, and the European and Pacific people have increased. The gap in degree holders among Māori has increased from 6.8 percentage points to 9.5 percentage points, an increase of 39.7 per cent, while the gap between the European population and Pacific people has increased from 7.6 percentage points to 11.5 percentage points, an increase of 51.3 per cent.

\section{Tertiary Participation Rates}

Table 9 shows age-standardised tertiary participation rates. This measure shows the percentage of the population aged 15 years and older who are enrolled in tertiary education at any time during the year. The measure does not capture private training establishments.

Table 9: Age-Standardised Tertiary Participation Rates ${ }^{69}$

\begin{tabular}{|l|l|l|l|l|}
\hline & $\mathbf{2 0 0 1}$ & $\mathbf{2 0 1 2}$ & $\begin{array}{l}\text { Absolute Change } \\
\mathbf{( 2 0 1 2 - 2 0 0 1 )}\end{array}$ & $\begin{array}{l}\text { Relative } \\
\text { Change }\end{array}$ \\
\hline European & $7.5 \%$ & $8.0 \%$ & $+0.5 \%$ & $6.7 \%$ \\
\hline Māori & $6.6 \%$ & $9.9 \%$ & $+3.3 \%$ & $50.0 \%$ \\
\hline Pacific people & $5.0 \%$ & $8.2 \%$ & $+3.2 \%$ & $64.0 \%$ \\
\hline Gap: European - Māori & $0.9 \%$ & $-1.9 \%$ & $-2.8 \%$ (gap is gone) & $-311.1 \%$ \\
\hline Gap: European - Pacific people & $2.5 \%$ & $-0.2 \%$ & $-2.7 \%$ (gap is gone) & $-108.0 \%$ \\
\hline
\end{tabular}

Data Source: Ministry of Education

Table 9 shows increases in tertiary participation among all three groups. However, greater participation rates are visible for Pacific people and Māori, with both achieving growth in participation of over 50 per cent in the 11-year period investigated. This high growth result has resulted in higher age-standardised tertiary participation rates for Pacific people and Māori than the European population. Thus, the gap in tertiary participation rates has now been eliminated. However, a similar trend over the 11-year time period investigated was visible for all three ethnic groups. This pattern shows increases in tertiary participation for the first part of the period examined (to participation levels of 8.7 per cent, 11.4 per cent and 8.5 per cent for Europeans, Māori and Pacific people respectively), which have been in decline in recent years.

\section{Paid Work}

This section examines indicators relating to work. There are multiple reasons why participation in paid work is desirable. The Welfare Working Group outlines these as providing access to higher incomes, increasing social contact, enhancing self-esteem, together with increasing evidence that it is beneficial for mental and physical health. ${ }^{70}$ Moreover, the wider community 
benefits through increased economic activity, as well as reducing the overall burden on the welfare system. This section provides data on five indicators relating to work: unemployment; employment; workplace injury; weekly earnings; and people receiving welfare benefits.

\section{Unemployment}

The first indicator of work is the December quarterly unemployment rates for 2003 and 2012. These figures are shown in Table 10.

Table 10: December Quarterly Unemployment ${ }^{71}$

\begin{tabular}{|l|l|l|l|l|}
\hline & $\mathbf{2 0 0 3}$ & $\mathbf{2 0 1 2}$ & $\begin{array}{l}\text { Absolute Change } \\
(\mathbf{2 0 1 2 - 2 0 0 3 )}\end{array}$ & $\begin{array}{l}\text { Relative } \\
\text { Change }\end{array}$ \\
\hline European & $3.2 \%$ & $5.5 \%$ & $+2.3 \%$ & $71.9 \%$ \\
\hline Māori & $10 \%$ & $14.8 \%$ & $+4.8 \%$ & $48.0 \%$ \\
\hline Pacific people & $8.8 \%$ & $16 \%$ & $+7.2 \%$ & $81.8 \%$ \\
\hline Gap: European - Māori & $-6.8 \%$ & $-9.3 \%$ & $-2.5 \%$ (increasing gap) & $36.8 \%$ \\
\hline $\begin{array}{l}\text { Gap: European - Pacific } \\
\text { people }\end{array}$ & $-5.6 \%$ & $-10.5 \%$ & $-4.9 \%$ (increasing gap) & \\
\hline
\end{tabular}

Data Source: Statistics New Zealand Household Labour Force Survey

Table 10 indicates that unemployment increased for all ethnic groups over the time period examined. Logistic regression shows that the unemployment rate increased significantly from December 2003 to December 2012 ( $\mathrm{p}<.0005)$. Moreover, the unemployment rates were significantly different by ethnic group both at December 2003 and December $2012\left(\mathrm{X}^{2}(2)\right.$, $\mathrm{p}<.0005$ in both cases). For both Māori and Pacific people, the gap with the European unemployment rate increased from December 2003 to December 2012. However, the gap increased by a significantly higher proportion for Pacific people as compared to Māori: 87.5 per cent for Pacific people and 36.8 per cent for Māori.

\section{Employment}

The employment indicator investigates the employment rate among Europeans, Māori and Pacific people. The employment rate measure captures those aged between 15 and 64, who work for one hour or more per week. These figures are outlined in Table 11.

Table 11: December Quarterly Employment ${ }^{72}$

\begin{tabular}{|l|l|l|l|l|}
\hline & $\mathbf{2 0 0 3}$ & $\mathbf{2 0 1 2}$ & $\begin{array}{l}\text { Absolute Change } \\
\mathbf{( 2 0 1 2 - 2 0 0 3 )}\end{array}$ & $\begin{array}{l}\text { Relative } \\
\text { Change }\end{array}$ \\
\hline European & $66.7 \%$ & $65.0 \%$ & $-1.7 \%$ & $-2.5 \%$ \\
\hline Māori & $58.1 \%$ & $55.2 \%$ & $-2.9 \%$ & $-5.0 \%$ \\
\hline Pacific people & $56.7 \%$ & $50.1 \%$ & $-6.6 \%$ & $-11.6 \%$ \\
\hline Gap: European - Māori & $8.6 \%$ & $9.8 \%$ & $+1.2 \%$ (increasing gap) & $14.0 \%$ \\
\hline Gap: European - Pacific people & $10.0 \%$ & $14.9 \%$ & $+4.9 \%$ (increasing gap) & $49.0 \%$ \\
\hline
\end{tabular}

Data Source: Statistics New Zealand Household Labour Force Survey

All ethnic groups show decreases in employment over the period examined. Logistic regression analysis shows that the employment rate decreased significantly between December 2003 and December 2012. Moreover, in both December 2003 and December 2012 the employment rate was significantly different by ethnic group $\left(\mathrm{X}^{2}, \mathrm{p}<.0005\right)$. The employment rate for both Māori and Pacific people decreased significantly more than the employment rate 
for Europeans over this time, with a larger decrease for Pacific people than for Māori at 49 per cent for Pacific people and 14 per cent for Māori. While the overall reduction in employment is likely to reflect the harsher economic environment in 2012, as compared to 2002, this does not account for the increasing gaps in employment between Europeans and Māori, or Europeans and Pacific people.

While the measures of paid work show all ethnic groups moving in the same direction, that is, increasing levels of unemployment and decreasing levels of employment, the figures show that Māori and Pacific people are over-represented in both categories. This suggests that the economic downturn has had greater impact on Māori and Pacific people, which may result from Māori and Pacific people being over-represented in lower-skill occupations that are more susceptible to job losses in harsher economic environments.

\section{Workplace Injury}

Workplace injury rates are outlined in Table 12. This indicator reports the rate of workplace injury per 1,000 full-time equivalent employees.

Table 12: Workplace Injury Claims (per 1,000 full-time equivalent workers) ${ }^{73}$

\begin{tabular}{|l|l|l|l|l|}
\hline & $\mathbf{2 0 0 3}$ & $\mathbf{2 0 1 2}$ & $\begin{array}{l}\text { Absolute Change } \\
(\mathbf{2 0 1 2 - 2 0 0 3 )}\end{array}$ & $\begin{array}{l}\text { Relative } \\
\text { Change }\end{array}$ \\
\hline European & 129 & 87 & -42 & $-32.6 \%$ \\
\hline Māori & 179 & 90 & -89 & $-49.7 \%$ \\
\hline Pacific people & 150 & 111 & -39 & $-26.0 \%$ \\
\hline Gap: European - Māori & -50 & -3 & +47 (closing gap) & $-94.0 \%$ \\
\hline Gap: European - Pacific people & -21 & -24 & -3 (increasing gap) & $14.3 \%$ \\
\hline
\end{tabular}

Data Source: Statistics New Zealand Injury Statistics

While all three ethnic groups have reduced workplace injury claims over the time period shown, the most significant decline is visible among the Māori population, at 94 per cent. For both 2003 and 2012, there was a significant difference in incidence of workplace injury claims between the three ethnic groups $\left(\mathrm{X}^{2}\right.$ test, $\left.\mathrm{p}<.0005\right)$. When the data from 2003 was compared with the data from 2012, again there was a significant reduction in incident rate (logistic regression model, $\mathrm{p}<.0005)$. However, although the gap between Pacific people and Europeans was greater in 2012 than in $2003(\mathrm{p}<.005)$, for Māori, the gap with Europeans was significantly lower in 2012 than in 2003 ( $\mathrm{p}<.0005)$.

\section{Weekly Earnings}

The median weekly earnings indicator reports on incomes received from wages and salaries. These figures are outlined in Table 13 for 2003 and 2013. 
Table 13: Median Weekly Earnings ${ }^{74}$

\begin{tabular}{|l|l|l|l|l|}
\hline & $\mathbf{2 0 0 3}$ & $\mathbf{2 0 1 3}$ & $\begin{array}{l}\text { Absolute } \\
\text { Change } \\
\mathbf{2 0 1 3 -} \\
\mathbf{2 0 0 3}\end{array}$ & $\begin{array}{l}\text { Relative } \\
\text { Change } \\
\mathbf{( 2 0 1 3 - 2 0 0 3 )}\end{array}$ \\
\hline European & $\$ 614 \pm 12.28$ & $\$ 863 \pm 17.26$ & $+\$ 249$ & $40 \%$ \\
\hline Māori & $\$ 540 \pm 10.8$ & $\$ 767 \pm 15.34$ & $+\$ 227$ & $42 \%$ \\
\hline Pacific people & $\$ 500 \pm 10.0$ & $\$ 712 \pm 14.24$ & $+\$ 212$ & $42.4 \%$ \\
\hline Gap: European - Māori & $\$ 74$ & $\$ 96$ & $+\$ 22$ & $29.7 \%$ \\
\hline $\begin{array}{l}\text { Gap: European - Pacific } \\
\text { people }\end{array}$ & $\$ 114$ & $\$ 151$ & $+\$ 37$ & $32.5 \%$ \\
\hline
\end{tabular}

Data Source: Statistics New Zealand Household Labour Force Survey

All groups show increased median weekly earnings over the period investigated. Europeans' median weekly earnings increased by 40 per cent, while both Māori and Pacific peoples' median weekly earnings increased by 42 per cent. Both Māori and Pacific people have significantly lower median weekly earnings in both 2003 and 2013 (z test, p<.05). In addition, for each ethnicity, the change from 2003 to 2012 is statistically significant (z test, $p<.05$ ). However, for both Māori people and Pacific people the difference from the European ethnic group does not change significantly from 2003 to 2013.

\section{Benefit Receipt}

The final indicator in the category of paid work investigates the percentage of the population receiving a core welfare benefit. These measures are reported as at 2001 and 2013 as the population prevalence has been calculated using census data. Long-term benefit receipt is strongly associated with low levels of education and training, as well as poorer health. ${ }^{75}$ This indicator uses a non-Māori, non-Pacific people comparison. The figures show the three ethnic groups as people in receipt of an income-tested benefit as a proportion of that ethnic group.

Table 14: Proportion of each Ethnic Group on Income-Tested Benefits ${ }^{76}$

\begin{tabular}{|l|l|l|l|l|}
\hline & $\mathbf{2 0 0 1}$ & $\mathbf{2 0 1 3}$ & $\begin{array}{l}\text { Absolute Change } \\
\mathbf{( 2 0 1 3 - 2 0 0 1 )}\end{array}$ & $\begin{array}{l}\text { Relative } \\
\text { Change }\end{array}$ \\
\hline Non-Māori, Non-Pacific people & $8.2 \%$ & $6.2 \%$ & $-2.0 \%$ & $-24.4 \%$ \\
\hline Māori & $17.7 \%$ & $20.0 \%$ & $+2.3 \%$ & $+13.0 \%$ \\
\hline Pacific people & $11.0 \%$ & $9.5 \%$ & $-1.5 \%$ & $-13.6 \%$ \\
\hline $\begin{array}{l}\text { Gap: Non-Māori, Non-Pacific people } \\
\text { - Māori }\end{array}$ & $-9.5 \%$ & $-13.8 \%$ & $\begin{array}{l}-4.3 \% \text { (increasing } \\
\text { gap) }\end{array}$ & $+45.3 \%$ \\
\hline $\begin{array}{l}\text { Gap: Non-Māori, Non-Pacific people } \\
\text { - Pacific people }\end{array}$ & $-2.8 \%$ & $-3.3 \%$ & $\begin{array}{l}-0.5 \% \text { (increasing } \\
\text { gap) }\end{array}$ & $+17.9 \%$ \\
\hline
\end{tabular}

Data Source: Ministry of Social Development

Benefit receipt is one of only two indicators investigated in this study where different patterns in absolute and relative change are visible among the three ethnic groups (the other is housing affordability, shown in Table 17). Table 14 shows that receipt of welfare benefits has decreased for the non-Māori, non-Pacific people; and Pacific people. However, this indicator shows an increase for Māori people. Despite the improvement for Pacific people, the gap is increasing between non-Māori, non-Pacific people and Pacific people. This gap is also increasing for Māori people. 


\section{Economic Standard of Living}

The indicator of economic standard of living relates to the "physical circumstances in which people live, the goods and services they are able to consume and the economic resources to which they have access."77 Two of the indicators investigated in this section relate to incomes and the other two relate to housing.

\section{Median Income}

The single most important driver in increasing inequality across OECD countries has been greater inequality in wages and salaries. ${ }^{78}$ Increasing household incomes is one tool to improve living standards and reduce poverty. This measure captures the changes in median weekly income over the period from 2003 to 2013 . The difference between the median weekly income in Table 15 and the weekly earnings measure outlined in Table 13 is Table 15 incorporates income from all sources, including earnings from employment.

Table 15: Median Weekly Income ${ }^{79}$

\begin{tabular}{|l|l|l|l|l|}
\hline & $\mathbf{2 0 0 3}$ & $\mathbf{2 0 1 3}$ & $\begin{array}{l}\text { Absolute Change } \\
\mathbf{( 2 0 1 3 - 2 0 0 3 )}\end{array}$ & $\begin{array}{l}\text { Relative } \\
\text { Change } \\
\mathbf{( 2 0 1 3 - 2 0 0 3 )}\end{array}$ \\
\hline European & $\$ 439 \pm 8.78$ & $\$ 620 \pm 12.4$ & $+\$ 181$ & $41.2 \%$ \\
\hline Māori & $\$ 373 \pm 7.46$ & $\$ 486 \pm 9.72$ & $+\$ 113$ & $30.3 \%$ \\
\hline Pacific people & $\$ 360 \pm 7.2$ & $\$ 381 \pm 7.62$ & $+\$ 21$ & $5.8 \%$ \\
\hline $\begin{array}{l}\text { Gap: European - Māori } \\
\$ 66\end{array}$ & $\$ 134$ & $\$ 68$ (increasing gap) & $103 \%$ \\
\hline $\begin{array}{l}\text { Gap: European - } \\
\text { Pacific people }\end{array}$ & $\$ 79$ & $\$ 239$ & $\$ 160$ (increasing gap) & $203 \%$ \\
\hline
\end{tabular}

Data Source: Statistics New Zealand New Zealand Income Survey

Table 15 shows increases in median weekly income for all ethnicities. However, the European population has increased by a considerably larger amount than for Pacific and Māori people. The median weekly income for Pacific people has increased by 5.8 per cent, while the increase for Māori is 30.3 per cent and Europeans is 41.2 per cent. The gap in median weekly income for both Māori and Pacific people has increased over the ten-year period examined: the gap has increased by $\$ 68$ for Māori (103 per cent) and $\$ 160$ for Pacific people (203 per cent).

The relative sampling errors for median weekly income from the New Zealand Income Survey are $\pm 2 \%$ and the standard errors quoted in Table 15 are based on this. Using a standard normal statistic to compare these medians we have:

$\begin{array}{lll} & 2003 & 2013 \\ \text { European vs Māori } & \mathrm{p}<.0001 & \mathrm{p}<.0001 \\ \text { European vs Pacific People } & \mathrm{p}<.0001 & \mathrm{p}<.0001\end{array}$

\section{Personal Income Distribution}

In the original Ministry of Social Development studies, the measure used for low-income was a low-income family unit indicator, which captured those earning 60 per cent or less of the median income. However, this measure is not available in the same form over an extended time period. Therefore, we are reporting on ethnic representation in the lowest quintile of incomes as collected in the New Zealand Income Survey. The figures shown in Table 16 represent personal income distribution by quintile, as a proportion of that ethnic group. 
Table 16: Personal Income Distribution in Lowest Quintile ${ }^{80}$

\begin{tabular}{|l|l|l|l|l|}
\hline & $\mathbf{2 0 0 3}$ & $\mathbf{2 0 1 3}$ & $\begin{array}{l}\text { Absolute Change } \\
\mathbf{( 2 0 1 3 - 2 0 0 3 )}\end{array}$ & $\begin{array}{l}\text { Relative } \\
\text { Change }\end{array}$ \\
\hline European & $16.5 \%$ & $17.1 \%$ & $+0.6 \%$ & $3.6 \%$ \\
\hline Māori & $20.2 \%$ & $24 \%$ & $+3.8 \%$ & $18.8 \%$ \\
\hline Pacific people & $26.2 \%$ & $31.2 \%$ & $+5 \%$ & $19.1 \%$ \\
\hline Gap: European - Māori & $-3.7 \%$ & $-6.9 \%$ & $-3.2 \%$ (increasing gap) & $86.5 \%$ \\
\hline Gap: European - Pacific people & $-9.7 \%$ & $-14.1 \%$ & $-4.4 \%$ (increasing gap) & $45.4 \%$ \\
\hline
\end{tabular}

Data Source: Statistics New Zealand New Zealand Income Survey

Table 16 shows that all ethnic groups have had increases in their proportional representation in the lowest income quintile over the 10-year period shown. However, the largest increases in representation in the lowest personal income quintile are visible among Pacific people with a 5 percentage point increase (19.1 per cent) and Māori with a 3.8 percentage point increase (18.8 per cent). In addition, the gap in representation in the lowest income quintile between European and Māori has increased 3.2 percentage points (86.5 per cent), while the gap in representation between European and Pacific people has increased 4.4 percentage points (45.4 per cent).

We used the chi-square test to compare percentages between years and between ethnic groups. For all ethnic groups, the percentage in the lowest quintile significantly increased from 2003 to 2013 (chi-squared test, p<.0005). For 2003 and 2013, all ethnic groups were significantly different from the other ethnic groups (chi-square test, $\mathrm{p}<.0005$ ).

\section{Housing Affordability}

The housing affordability indicator considers the proportion of households that have a housing cost to disposable income ratio of at least 30 per cent. These figures are outlined in Table 17. A 12-year period is investigated for these measures, as the data is from the New Zealand Census.

Table 17: Housing Affordability - Housing Costs Greater Than 30\% of Disposable Household Income ${ }^{81}$

\begin{tabular}{|l|l|l|l|l|}
\hline & $\mathbf{2 0 0 1}$ & $\mathbf{2 0 1 3}$ & $\begin{array}{l}\text { Absolute Change } \\
(\mathbf{2 0 1 3 - 2 0 0 1})\end{array}$ & $\begin{array}{l}\text { Relative } \\
\text { Change }\end{array}$ \\
\hline $\begin{array}{l}\text { European households as a } \\
\text { proportion of European households }\end{array}$ & $22.6 \%$ & $25.7 \%$ & $+3.1 \%$ & $13.7 \%$ \\
\hline $\begin{array}{l}\text { Māori households as a proportion } \\
\text { of Māori households }\end{array}$ & $34.9 \%$ & $31.7 \%$ & $-3.2 \%$ & $-9.2 \%$ \\
\hline $\begin{array}{l}\text { Pacific people households as a } \\
\text { proportion of Pacific households }\end{array}$ & $41.6 \%$ & $41.2 \%$ & $-0.4 \%$ & $-1.0 \%$ \\
\hline Gap: European - Māori & $-12.3 \%$ & $-6 \%$ & $6.3 \%$ (closing gap) & $-51.2 \%$ \\
\hline Gap: European - Pacific people & $-19 \%$ & $-15.5 \%$ & $3.5 \%$ (closing gap) & $-18.4 \%$ \\
\hline
\end{tabular}

Data Source: Statistics New Zealand Census of Population and Dwellings

Table 17 shows that housing affordability as captured by the measure of the proportion of households where housing costs are at least 30 per cent of disposable income have increased for European households, but reduced for Māori and Pacific households over the 12 year period shown. While Māori and Pacific households retain a higher proportion of households with high housing costs, the gaps between both these ethnic groups and European households have 
reduced over the 12 year period investigated. The gap has reduced by around half (51.2 per cent) for Māori households, while a smaller reduction of 18.4 per cent is visible for Pacific households.

\section{Household Crowding}

The household crowding measure uses the Canadian National Occupancy standard, which allocates bedrooms based on age, sex and relationships of household members. The measure shown in Table 18 is where at least one more bedroom is needed in the household. As census data is also used for this indicator, a 12 year period is used for analysis.

Table 18: Household Crowding ${ }^{82}$

\begin{tabular}{|l|l|l|l|l|}
\hline & $\mathbf{2 0 0 1}$ & $\mathbf{2 0 1 3}$ & $\begin{array}{l}\text { Absolute Change } \\
(\mathbf{2 0 1 3 - 2 0 0 1 )}\end{array}$ & $\begin{array}{l}\text { Relative } \\
\text { Change }\end{array}$ \\
\hline $\begin{array}{l}\text { European households as a } \\
\text { proportion of European } \\
\text { households }\end{array}$ & $3 \%$ & $2.7 \%$ & $-0.3 \%$ & $-10.0 \%$ \\
\hline $\begin{array}{l}\text { Māori households as a proportion } \\
\text { of Māori households }\end{array}$ & $13.1 \%$ & $11 \%$ & $-2.1 \%$ & $-16.0 \%$ \\
\hline $\begin{array}{l}\text { Pacific people households as a } \\
\text { proportion of Pacific households }\end{array}$ & $25.8 \%$ & $23.7 \%$ & $-2.1 \%$ & $-8.1 \%$ \\
\hline Gap: European - Māori & $-10.1 \%$ & $-8.3 \%$ & $1.8 \%$ (closing gap) & $-17.8 \%$ \\
\hline Gap: European - Pacific people & $-22.8 \%$ & $-21 \%$ & $1.8 \%$ (closing gap) & $-7.9 \%$ \\
\hline
\end{tabular}

Data Source: Statistics New Zealand Census of Population and Dwellings

Table 18 shows that both Māori households and Pacific households have significantly higher levels of household crowding than European households. All ethnic groups have shown declines in the overall proportions of household crowing and reductions in gaps are visible between Māori households and European households (17.8 per cent), and Pacific households and European households (7.9 per cent). Despite the reductions in these gaps over the 12 year period, large gaps in household crowding remain.

\section{Cultural Identity}

Reference to culture relates to "the customs, practices, languages, values and world views that define social groups." ${ }^{83}$ Cultural identity can contribute to a person's wellbeing. ${ }^{84}$ Two measures of cultural identity are examined in this study: proportions of Māori people who speak Māori language and proportions of people in Māori-medium education.

\section{Māori Language Speakers}

The first indicator is the proportion of individuals who identify as Māori who speak the Māori language. Table 19 shows a decline in this indicator of 3.9 percentage points over the 12 year period investigated. The decline was evident in the 2006 census results, where a 1.5 percentage point decline was visible. However, there has been a further 2.4 percentage point decline over the subsequent seven year period since the 2006 census. 
Table 19: Māori Language Speakers ${ }^{85}$

\begin{tabular}{|l|l|l|l|l|}
\hline & 2001 & 2013 & $\begin{array}{l}\text { Absolute } \\
\text { Change } \\
\mathbf{( 2 0 1 3 - 2 0 0 1 )}\end{array}$ & $\begin{array}{l}\text { Relative } \\
\text { Change }\end{array}$ \\
\hline $\begin{array}{l}\text { Proportion of Māori who speak Māori } \\
\text { language }\end{array}$ & $24.8 \%$ & $20.9 \%$ & $-3.9 \%$ & $-15.7 \%$ \\
\hline
\end{tabular}

Data Source: Statistics New Zealand Census of Population and Dwellings

\section{Māori Medium Education}

The second indicator of cultural identity is Māori medium education. Māori medium education captures students who are taught in Māori language for at least 51 per cent of the time (at least 12.5 hours per week). Table 20 shows that in 2013, 17,343 students received at least 51 per cent of course work as Māori medium education. This compares to 16,342 in 2001.

Table 20: Māori Medium Education Participation ${ }^{86}$

\begin{tabular}{|l|l|l|l|l|}
\hline & $\mathbf{2 0 0 1}$ & $\mathbf{2 0 1 3}$ & $\begin{array}{l}\text { Absolute } \\
\text { Change } \\
\mathbf{( 2 0 1 3 -} \\
\mathbf{2 0 0 1}\end{array}$ & $\begin{array}{l}\text { Relative } \\
\text { Change }\end{array}$ \\
\hline Māori Medium Education Students & 16,342 & 17,343 & $+1,001$ & $6.1 \%$ \\
\hline Māori students & 149,473 & 175,456 & 25,983 & $17.4 \%$ \\
\hline $\begin{array}{l}\text { Proportion of Māori students in Māori } \\
\text { Medium Education }\end{array}$ & $10.9 \%$ & $9.9 \%$ & $-1.0 \%$ & $-9.2 \%$ \\
\hline
\end{tabular}

Data Source: Ministry of Education

There has been an increase of 1,001 students participating in Māori medium education. However, as the proportion of Māori students has increased by nearly 26,000 during the time period investigated, this has resulted in a reduced proportion of Māori students participating in Māori medium education, from 10.9 per cent to 9.9 per cent.

\section{Social Connectedness}

In the 2003 MSD report, two social connectedness measures were reported: telephone and internet access in the home and participation in family/whänau activities and regular contact with family/friends. In 2003, indicators captured the proportion of the population with access to a telephone and the proportion of the population with access to the internet. At this time, $97 \%$ of the population had access to a telephone. However, in 2012, households with access to a landline have reduced to $87 \%$. As this result is less likely to represent an inequality increase and more likely to indicate changing use of technology, as people replace landlines with mobile telephones, we have chosen to only report on internet access in this social connectedness measure.

\section{Internet Access in the Home}

Table 21 outlines the proportion of households that have access to the internet. We have not been able to obtain data for this measure from the same data source across the two time periods. Thus, the data provided in Table 21 is unsuitable for further analysis. However, it does provide an indication of increased household internet access for all ethnic groups. While 86 per cent of the European population had access to the internet at home in 2012, only 68 per cent of Māori people and 65 per cent of Pacific people had internet access in the home. The datasets used 
suggest that the gaps for both ethnicities had increased over the 11 year period investigated. In 2001, the gap between Europeans and Māori was 8 percentage points. This had increased to 18 percentage points by 2012, an increase of 125 per cent. Similarly, the gap between Europeans and Pacific people was 12 percentage points in 2001. This had increased to 21 percentage points by 2012 , an increase of 75 per cent.

Table 21: Household Access to the Internet $^{87}$

\begin{tabular}{|l|l|l|l|l|}
\hline & $\mathbf{2 0 0 1}$ & $\mathbf{2 0 1 2}$ & $\begin{array}{l}\text { Absolute Change (2012- } \\
\mathbf{2 0 0 1}\end{array}$ & $\begin{array}{l}\text { Relative } \\
\text { Change }\end{array}$ \\
\hline European & $38 \%$ & $86 \%$ & $+48 \%$ & $126.3 \%$ \\
\hline Māori & $30 \%$ & $68 \%$ & $+38 \%$ & $126.7 \%$ \\
\hline Pacific people & $26 \%$ & $65 \%$ & $+39 \%$ & $150 \%$ \\
\hline Gap: European - Māori & $8 \%$ & $18 \%$ & $+10 \%$ (increasing gap) & $125 \%$ \\
\hline Gap: European - Pacific people & $12 \%$ & $21 \%$ & $+9 \%$ (increasing gap) & $75 \%$ \\
\hline
\end{tabular}

Data Source: Statistics New Zealand

\section{Discussion}

The report produced by MSD in 2003 frequently reports no clear trend or improvements among many of the indicators outlined in section four of this article. This is no longer the case for most of the indicators reported on in this study. The majority of the indicators investigated in this study suggest worsening outcomes for Māori and Pacific people in the form of increasing gaps in indicators when compared to the European population. Moreover, some of the indicators that produce improving outcomes still retain large gaps between the European population and Māori or Pacific people. As noted by the Cabinet Social Development Committee, most people want a society where everyone has the same opportunity to participate and succeed, and where factors such as ethnicity and family background do not impact on one's future opportunities. ${ }^{88}$ However, the data outlined above suggests that significant inequality not only remains in New Zealand, but is also escalating as measured by growing gaps in many inequality indicators.

New Zealand has a relatively generous welfare system, as well as a system of taxes and transfers that are intended to redistribute income to those in need. Redistribution through taxes and transfers reduces income inequality to well below where it would otherwise be. ${ }^{89}$ However, despite the redistribution, the gaps in many of the inequality indicators between Europeans and Māori, and Europeans and Pacific people remain high. This issue is highlighted by the OECD in observing that inequality, as measured by the Gini coefficient, has not improved as significantly as might be expected, given the increased focus on inequality in recent times. ${ }^{90}$ However, the OECD note that the relatively modest increase in inequality over the previous 20 years "hides a larger underlying trend," which is the practice in developed countries to tax more and spend more to offset the movement towards higher inequality. ${ }^{91}$ As noted by the OECD, spending on social policy now is higher than at any time in history and "if governments stop trying to offset the inequalities by either spending less on social benefits, or by making taxes and benefits less targeted to the poor, then the growth in inequality would be much more rapid." "92 Moreover, the OECD observes that relying on taxing more and spending more as a response to inequality can only be a temporary measure. ${ }^{93}$

The OECD suggests that tax pays a less important role than benefits in reducing income inequalities. ${ }^{94}$ This has become more the case over the past decade or two, where income taxes have become less progressive and traditional forms of "wealth" taxes (such as estate taxes and gift duties) have been reduced or repealed. The New Zealand tax system is no different: goods and services tax has increased; the progressiveness of the income tax system has reduced; no comprehensive capital gains tax exists; and no estate or gift duty is in place. However, this does 
not mean that the tax system does not have a role to play in reducing income inequalities. Piketty observes the importance of inherited wealth as compared to income from labour. ${ }^{95}$ To the extent that inherited wealth or capital assets are not taxed, opportunities to address inequality are limited. Opportunities to tax wealth or capital assets in New Zealand are poorly utilised and taking into account the gaps in society highlighted throughout this article, this may be the time to engage in a wider debate on the role of the tax system in tackling inequality.

The OECD proposes that the labour market should be the first place that governments look towards to address rising inequality: "the only sustainable way to reduce inequality is to stop the underlying widening of wages and income from capital. In particular, we have to make sure that people are capable of being in employment and earning wages that keep them and their families out of poverty." 96 Well educated, high-income earning workers have achieved higher gains in recent times, while those with fewer skills have not. ${ }^{97}$ The outcome of greater disparities in wages has contributed to greater involvement of the state in assisting low-income earners to maintain a moderate standard of living.

Reforming tax and benefit policies is "the most direct and powerful instrument for redistribution." 98 However, the tool that has the most promise for addressing inequality is employment. This has a clear link to education and ensuring that workers have sufficient skills to take on skilled employment. The OECD propose that "upskilling is singled out as the only force which succeeded not only in reducing wage dispersion but also in increasing employment rates." $" 99$ Thus, the OECD note the importance of investing in people - a process that must begin in early childhood and be followed through into more formal education to ensure that children from households with fewer resources have opportunities to engage in education and achieve their full potential. ${ }^{100}$ The Royal Society of New Zealand observe the contrast between "workrich" households and "work-poor" households. ${ }^{101}$ Work-rich households are generally those where individuals hold post-secondary qualifications. Work-poor households "either have qualifications inappropriate to a changed labour market or lack advanced credentials altogether." 102

That Māori and Pacific people are disproportionately poorly represented in social indicators is not a new trend. We acknowledge that the causes are complex. Some of the issues are entrenched in historic intergenerational disparities of wealth and inheritance. The issues are also informed by past experiences in the health or education systems. These remain issues that need to be considered in addressing the current ethnic disparities in New Zealand.

Despite considerable attention paid to the issue, the data outlined in this research indicates that New Zealand's strategy to address inequality as it relates to Māori and Pacific people has had limited success. Some indicators have improved, but the majority have not. Redistribution minimises the symptoms of the problem, at least to some extent, but it does not address the underlying causes of inequality. Ten years ago, when the MSD reports that this study is based on were produced, there appeared to be a strategic multi-agency approach towards addressing inequality, with reports suggesting 109 initiatives were ongoing in 2004. This no longer appears to be the case. During the course of this research, we found no multiagency attempts to monitor progress of these social measures. Moreover, the difficulty experienced in obtaining comparable data suggests that, in some cases, data is no longer captured on some of the original measures. We acknowledge the recent release of the $T e$ Kupenga 2013 survey data, which is an encouraging sign in potential monitoring of Māori indicators of wellbeing. However, currently this is a single survey. A similar survey for Pacific people would appear warranted, along with an indication that the survey will be repeated at regular intervals to allow monitoring to continue.

As observed by the OECD there is nothing inevitable about either high or increasing inequalities. ${ }^{103}$ The majority of the indicators investigated in this study show worsening outcomes for Māori and Pacific people. Of those indicators where closing gaps are visible, in 
many cases, large gaps still remain. This growing gap in inequality between, on the one hand, Māori and Pacific people, and on the other, the European population, warrants greater government attention if the gaps are not to continue increasing into the future.

We acknowledge the limitations of a study such as this. There are inherent difficulties with making generalisations from a selected time period. There is the possibility for movements within the time period to be smoothed, which may limit the visibility of additional trends in the measures discussed. The Global Financial Crisis is likely to be a factor in the outcome of some of the indicators, which may be obscured with some of the time periods utilised. Nonetheless, using the original Ministry of Social Development study as a base line, this research provides an option for additional studies to track performance into the future.

\section{Conclusion}

Inequality in New Zealand is mitigated to some extent through the tax and transfer system. However, this is not a long-term solution to address inequality. Moreover, it has the greatest benefit for those in the workforce. Among the weaker measures reported above are those of employment/unemployment and income. These measures subsequently have an effect on other indicators, such as health. The OECD suggests that focusing on ensuring people can engage effectively in employment is crucial to reducing inequality. One way to achieve this is through education and skill development. This will enhance the employment opportunities and earning capacity for those who are among the "least equal" in society and is one way in which we can address inequality in New Zealand. The measures discussed above suggest that success in education measures for Māori and Pacific people have yet to flow through to the tertiary level where they may have greatest impact.

There is the potential for the tax system to play a more proactive role in addressing inequality in New Zealand. At the present time there are no wealth taxes, such as inheritance taxes, and the majority of capital gains are not subject to tax. As noted by Piketty, returns to capital historically have exceeded returns to income. As returns to capital in New Zealand are largely untaxed, this limits opportunities to engage in greater redistribution, which may assist in addressing inequality.

This research indicates that while New Zealand has had some successes in reducing inequalities, the gaps in inequality among the majority of the indicators investigated in this study show worsening outcomes for Māori and Pacific people. This growing gap in inequality between Māori and Pacific people, and the European population, warrants greater government attention if the gaps are not to continue increasing into the future. 


\section{Appendix I: Summary of Indicators and Findings}

\begin{tabular}{|c|c|c|c|c|c|c|c|}
\hline Group & Table & Indicator & European & Māori & Pacific & $\begin{array}{l}\text { Gap } \\
\text { (European } \\
\text { \& Māori) } \\
\end{array}$ & $\begin{array}{l}\text { Gap } \\
\text { (European } \\
\text { \& Pacific) } \\
\end{array}$ \\
\hline \multirow{5}{*}{ Health } & 1 & Life expectancy at birth & Improved & Improved & N/A & Closing & N/A \\
\hline & 2 & Prevalence of cigarette smoking & Improved & Improved & Improved & Closing & Closing \\
\hline & 3 & Obesity & Worse & Worse & Worse & Increasing & Increasing \\
\hline & 4 & Age-standardised suicide rates & Mixed & Mixed & N/A & Increasing & N/A \\
\hline & 5 & Infant mortality rates & Improved & Improved & Improved & Closing & Closing \\
\hline \multirow{4}{*}{$\begin{array}{l}\text { Knowledge } \\
\text { and Skills }\end{array}$} & 6 & $\begin{array}{l}\text { Participation in early childhood } \\
\text { education }\end{array}$ & Improved & Improved & Improved & Closing & Closing \\
\hline & 7 & $\begin{array}{l}\text { School leavers with a } \\
\text { qualification of NCEA Level } 2 \text { or } \\
\text { higher }\end{array}$ & Improved & Improved & Improved & Closing & Increasing \\
\hline & 8 & $\begin{array}{l}\text { Proportion of the population with } \\
\text { a Bachelor's degree or higher }\end{array}$ & Improved & Improved & Improved & Increasing & Increasing \\
\hline & 9 & Tertiary participation rates & Improved & Improved & Improved & Gap is gone & Gap is gone \\
\hline \multirow{5}{*}{ Paid Work } & 10 & Unemployment & Worse & Worse & Worse & Increasing & Increasing \\
\hline & 11 & Employment & Worse & Worse & Worse & Increasing & Increasing \\
\hline & 12 & Workplace injury claims & Improved & Improved & Improved & Closing & Increasing \\
\hline & 13 & Median weekly earnings & Improved & Improved & Improved & Same & Same \\
\hline & 14 & $\begin{array}{l}\text { Percentage of the population } \\
\text { receiving a core benefit }\end{array}$ & Improved & Worse & Improved & Increasing & Increasing \\
\hline \multirow{4}{*}{$\begin{array}{l}\text { Economic } \\
\text { Standard of } \\
\text { Living }\end{array}$} & 15 & Median weekly income & Improved & Improved & Improved & Increasing & Increasing \\
\hline & 16 & Personal income distribution & Worse & Worse & Worse & Increasing & Increasing \\
\hline & 17 & Housing affordability & Worse & Improved & Improved & Closing & Closing \\
\hline & 18 & Household crowding & Improved & Improved & Improved & Closing & Closing \\
\hline \multirow{2}{*}{$\begin{array}{l}\text { Cultural } \\
\text { Identity }\end{array}$} & 19 & Māori language speakers & N/A & Worse & N/A & Worse & N/A \\
\hline & 20 & Māori medium education & N/A & Worse & N/A & Worse & N/A \\
\hline $\begin{array}{l}\text { Social } \\
\text { Connected- } \\
\text { ness }\end{array}$ & 21 & Internet access in the home & Improved & Improved & Improved & Increasing & Increasing \\
\hline
\end{tabular}


${ }^{1}$ Danny Dorling, Inequality and the 1\% (London: Verso, 2014).

${ }^{2}$ Organisation for Economic Cooperation and Development, Growing Unequal? Income Distribution and Poverty in OECD Countries (Paris: OECD, 2008).

${ }^{3}$ Cabinet Social Development Committee, Reducing Inequalities: Next Steps, Cabinet Social Development Committee (Wellington: Ministry of Social Development, 2004).

${ }^{4}$ Organisation for Economic Cooperation and Development, Divided We Stand: Why Inequality Keeps Rising (Paris: OECD, 2011), 3.

${ }^{5}$ Max Rashbrooke, ed., Inequality and New Zealand (Wellington: Bridget Williams Books, 2013).

${ }^{6}$ Ibid., 28.

${ }^{7}$ Ibid.

${ }^{8}$ Bryan Perry, 2013 Household Incomes Report - Key Findings (Wellington: Ministry of Social Development, 2013), 1.

${ }^{9}$ Ibid.

${ }^{10}$ Roy Morgan Research, "Finding No. 5111," accessed 8 April 2014, http://www.roymorgan.com.

${ }^{11}$ Ministry of Social Development, Social Indicators for the Pacific and Maori Populations

(Wellington: Ministry of Social Development, 2003).

${ }^{12}$ Ministry of Social Development, Attachment 1: Reducing Inequalities Indicators for Maori and

Pacific Peoples (Wellington: Ministry of Social Development, 2004).

${ }^{13}$ Cabinet Social Development Committee, Reducing Inequalities; Cabinet Social Development

Committee, Six-Monthly Report on Reducing Inequalities: January to June 2003 (Wellington:

Ministry of Social Development, 2004); Cabinet Social Development Committee, Six-Monthly Report on Reducing Inequalities: July to December 2003 (Wellington: Ministry of Social Development, 2004).

${ }^{14}$ Richard G. Wilkinson and Kate Pickett, The Spirit Level: Why Equality is Better for Everyone (London: Penguin Books, 2010); Thomas Piketty, Capital in the Twenty-First Century (London: Harvard University Press, 2013); Joseph E. Stiglitz, The Price of Inequality (London: WW Norton, 2013); Dorling, Inequality and the $1 \%$.

${ }^{15}$ Dorling, Inequality and the $1 \%, 3$.

${ }^{16}$ Miles Corak, "Income Inequality, Equality of Opportunity and Intergenerational Mobility," Journal of Economic Perspectives 27, no. 3 (2013): 79; Max Rashbrooke, "Why Income Gaps Matter: The Treasury and the Tricky Issue of Inequality," Policy Quarterly 10, no. 1 (2014): 3.

${ }^{17}$ Ganesh Nana, "The Cost of Inequality," in Inequality: A New Zealand crisis, ed. Max Rashbrooke (Wellington: Bridget Williams Books, 2013), 55.

${ }^{18}$ Ibid., 60.

${ }^{19}$ Ibid., 61.

${ }^{20}$ Richard G. Wilkinson, "Health Inequalities: Relative or Absolute Material Standards?" British Medical Journal 314 (1997): 591.

${ }^{21}$ John W. Lynch et al., "Income Inequality and Mortality,” British Medical Journal 320 (2000):1200.

22 Johan P. Mackenbach and Anton E. Kunst, "Measuring the Magnitude of Socio-Economic

Inequalities in Health: An Overview of Available Measures Illustrated with Two Examples from Europe," Social Science and Medicine 44, no. 6 (1997): 57; Johan P. Mackenbach et al.,

"Socioeconomic Inequalities in Health in 22 European Countries," The New England Journal of Medicine 358 (2008): 2468.

${ }^{23}$ Dorling, Inequality and the 1\%, 130.

${ }^{24}$ R. De Gelder et al., "Long-term Trends in Inequalities in Mortality in England and Wales, Finland and Norway," European Journal of Public Health 44 (2014): 308.

${ }^{25}$ Jonathan D. Ostry, Andrew Berg and Charalambos G. Tsangarides, Redistribution, Inequality and Growth (International Monetary Fund: Washington, 2014), 4.

${ }^{26}$ Cabinet Social Development Committee, Reducing Inequalities.

${ }^{27}$ Organisation for Economic Cooperation and Development, OECD Factbook 2013: Economic,

Environment and Social Statistics (Paris: OECD, 2013), 66. 
${ }^{28}$ Jonathan Cribb et al., Living Standards, Poverty and Inequality in the UK: 2013 (London: Institute for Fiscal Studies, 2013).

${ }^{29}$ Organisation for Economic Cooperation and Development, OECD Factbook 2013.

${ }^{30}$ Stiglitz, The Price of Inequality.

${ }^{31}$ Shlomo Yitzhaki, "On an Extension of the Gini Inequality Index," International Economic Review 24 (1983): 617.

${ }^{32}$ Organisation for Economic Cooperation and Development, Divided We Stand, 228.

${ }^{33}$ Child Poverty Action Group, "Income Inequality," accessed 2 May 2014, http://www.nzchildren.co.nz/document_downloads/H.\%202014\%20CPM\%20Child\%20Poverty\%20I ncome\%20Inequality.pdf.

${ }^{34}$ Organisation for Economic Cooperation and Development, "Datalab," accessed 3 April 2014, http://www.oecd.org/statistics/datalab/income-distribution-poverty.htm.

${ }^{35}$ Ibid.

${ }^{36}$ Organisation for Economic Cooperation and Development, Growing Unequal.

${ }^{37}$ Max Rashbrooke, ed., Why Inequality Matters (Wellington: Bridget William Books, 2013), 3.

${ }^{38}$ Bryan Perry, Household Incomes in New Zealand: Trends in Indicators of Inequality and Hardship 1982 to 2012 (Wellington: Ministry of Social Development, 2013), 124.

${ }^{39}$ Ibid.

${ }^{40}$ Ministry of Education, "Retention of Students in Senior Secondary Schools," accessed 2 May 2015, https://www.educationcounts.govt.nz/indicators/main/student-engagement-participation/1955.

${ }^{41}$ Ministry of Education, "School Leavers with At Least a Level 3 Qualification or a University Entrance Award," accessed 2 May 2015,

https://www.educationcounts.govt.nz/indicators/main/education-and-learning-outcomes/1891.

${ }^{42}$ Ministry of Business, Innovation and Employment, "Youth Labour Market Factsheet - March 2013," accessed 2 May 2015, http://www.dol.govt.nz/publications/lmr/pdfs/lmr-fs/lmr-fs-youthmar13.pdf.

${ }^{43}$ Refer to Cabinet Social Development Committee, Reducing Inequalities, Table 3: Reducing Inequalities Policies and Programmes, for a more comprehensive overview of policies and programmes targeted towards reducing inequalities.

${ }^{44}$ Cabinet Social Development Committee, Reducing Inequalities, 2.

${ }^{45}$ Cabinet Social Development Committee, Six-Monthly Report on Reducing Inequalities. The sixmonthly report was a report of departmental activity on initiatives to reduce inequality.

${ }^{46}$ Statistics New Zealand, "Statistical Standard for Ethnicity," accessed 9 July 2014, http://www.stats.govt.nz.

${ }^{47}$ Statistics New Zealand, "2013 Census - Major Ethnic Groups in New Zealand," accessed 9 July 2014, http://www.stats.govt.nz.

${ }^{48}$ These figures show the proportion of people who identified with this ethnic group. As individuals may identify with more than one ethnic group, the totals of the ethnic groups do not add to 100 per cent. Prioritisation (where the ethnic group of a person with multiple ethnic group identifications is assigned to just one ethnic group) is no longer used in official statistics in New Zealand, as it may mask diversity between ethnic groups. Statistics New Zealand, "The Impact of Prioritisation on the Interpretation of Ethnicity Data," accessed 12 May 2015, http://www.stats.govt.nz.

${ }^{49}$ Statistics New Zealand, "2013 Census - Major Ethnic Groups"

${ }^{50}$ For some indicators a non-Māori, non-Pacific comparison group, or a non-Māori comparison group, is used.

${ }^{51}$ Ross Barnett, Graham Moon and Robin Kearns, "Social Inequality and Ethnic Differences in Smoking in New Zealand," Social Science and Medicine 59 (2004): 129.

${ }^{52}$ S. Ajwani et al., Decades of Disparity: Ethnic Mortality Trends in New Zealand 1980-1999 (Wellington: Ministry of Health, 2003), iii.

${ }^{53}$ Dale Bramley et al., "Disparities in Indigenous Health: A Cross-Country Comparison Between New Zealand and the United States," American Journal of Public Health 95, no. 5 (2005): 844.

${ }^{54}$ Ajwani et al., "Decades of Disparity."

${ }^{55}$ Statistics New Zealand, "Life Expectancy at Birth," accessed 13 February 2014, http://www.stats.govt.nz. Life expectancy data is based on registered deaths in the period reported. 
${ }^{56}$ Statistics New Zealand, New Zealand Life Tables: 2005-07 (Wellington: Statistics New Zealand, 2009), 15.

${ }^{57}$ Tony Blakely et al., "What is the Contribution of Smoking and Socioeconomic Position to Ethnic Inequalities in Mortality in New Zealand?" The Lancet 368 (2006): 44.

${ }^{58}$ Ross Barnett, Jamie Pearce and Graham Moon "Does Social Inequality Matter? Changing Ethnic Socio-Economic Disparities and Maori Smoking in New Zealand, 1981-1996," Social Science and Medicine 60 (2005): 1515.

${ }^{59}$ Statistics New Zealand, "Census Data," accessed 2 May 2015, http://www.stats.govt.nz.

${ }^{60}$ Ministry of Social Development, Social Indicators.

${ }^{61}$ Ministry of Health, "New Zealand Health Survey," accessed 19 May 2014,

http://www.health.govt.nz. Obesity is defined as having a Body Mass Index higher than 30 for New Zealand European/other ethnicities, or greater than 32 for Māori and Pacific people. The measure is for those aged 15 years and over.

${ }^{62}$ Ministry of Health, Suicide Facts: Deaths and Intentional Self-Harm Hospitalisations (Wellington: Ministry of Health, 2010).

${ }^{63}$ Ministry of Health, "New Zealand Mortality Collection," accessed 15 February 2014, http://www.moh.govt.nz.

${ }^{64}$ Stiglitz, The Price of Inequality.

${ }^{65}$ Ministry of Social Development, The Social Report: 2010 (Wellington: Ministry of Social Development, 2010).

${ }^{66}$ Ministry of Education, "Prior Participation in Early Childhood Education: new entrants," accessed 2 April 2014, http://www.educationcounts.govt.nz/statistics.

${ }^{67}$ Ministry of Education, "Percentage of 18-Year-Olds with a Minimum of NCEA Level 2 or Equivalent," accessed 2 April 2014, http://www.educationcounts.govt.nz/statistics. Earlier statistical reports show the equivalent qualification as "Sixth Form Certificate or Higher."

${ }^{68}$ Statistics New Zealand, "Census 2013," accessed 10 July 2014, http://www.statistics.govt.nz; Statistics New Zealand, "Census 2001," accessed 10 July 2014, http://www.statistics.govt.nz. ${ }^{69}$ Ministry of Education, "Age Standardised Tertiary Participation Rates," accessed 25 February 2014, http://www.educationcounts.govt.nz. We include individuals participating in level four certificates (e.g. trade qualifications); diplomas; Bachelors; and other post-graduate qualifications (such as Masters and Doctorates) in the measure.

${ }^{70}$ Welfare Working Group, Welfare Working Group: Reducing Long-Term Benefit Dependency Recommendations (Wellington: Institute for Governance and Policy Studies, 2011), 55.

${ }^{71}$ Statistics New Zealand, "Household Labour Force Survey, December quarter 2005," accessed 1 March 2014, http://www.statistics.govt.nz; Statistics New Zealand, "Household Labour Force Survey, December quarter 2012," accessed 1 March 2014, http://www.statistics.govt.nz.

${ }^{72}$ Ibid.

${ }^{73}$ Statistics New Zealand, "Injury Statistics - Work-related claims,” accessed 14 March 2014, http://www.statistics.govt.nz.

${ }^{74}$ Statistics New Zealand, "Household Labour Force Survey," accessed 15 March 2014, http://www.statistics.govt.nz. Standard errors quoted are $\pm 2 \%$ as per the approach adopted by Statistics New Zealand.

${ }^{75}$ Welfare Working Group, Welfare Working Group, 46.

${ }^{76}$ Ministry of Social Development, "Key Facts at June 2004," accessed 9 April 2014, http://www.msd.govt.nz; Ministry of Social Development, "Key Facts at June 2013," accessed 9 April 2014, http://www.msd.govt.nz.

${ }^{77}$ Ministry of Social Development, The Social Report, 60.

${ }^{78}$ Organisation for Economic Cooperation and Development, Divided We Stand, 17.

${ }^{79}$ Statistics New Zealand, "New Zealand Income Survey, 2003," accessed 3 April 2014, http://www.stats.govt.nz; Statistics New Zealand, "New Zealand Income Survey, 2013," accessed 3 April 2014, http://www.stats.govt.nz.

${ }^{80}$ Ibid.

${ }^{81}$ Statistics New Zealand. Personalised dataset on housing affordability from Census data. Data received 16 June 2014. 
${ }^{82}$ Statistics New Zealand. Personalised dataset on housing crowding from Census data. Data received 16 June 2014.

${ }^{83}$ Ministry of Social Development, The Social Report, 84.

${ }^{84}$ Ministry of Social Development, The Social Report.

${ }^{85}$ Statistics New Zealand, "Census Data and Reports," accessed 15 April 2014, http://www.stats.govt.nz.

${ }^{86}$ Ministry of Education, "Māori Language in Education," accessed 3 April 2014, http://www.educationcounts.govt.nz/; Ministry of Education, "Student Numbers by Ethnicity," accessed 5 June 2014, http://www.educationcounts.govt.nz. Figures reported are based on the headcount of students enrolled in the school as at 1 July in the year shown.

${ }^{87}$ Statistics New Zealand, "Household Use of Information and Communication Technology Survey (2012)," accessed 10 April 2014, http://www.statistics.govt.nz; Statistics New Zealand, "2001, Census of Population and Dwellings. Household Access to the Internet," accessed 10 April 2014, http://www.statistics.govt.nz.

${ }^{88}$ Cabinet Social Development Committee, Reducing Inequalities.

${ }^{89}$ Perry, Household Incomes Report.

${ }^{90}$ Organisation for Economic Cooperation and Development, Growing Unequal.

${ }^{91}$ Ibid.

${ }^{92}$ Ibid., 3.

${ }^{93}$ Organisation for Economic Cooperation and Development, Growing Unequal.

${ }^{94}$ Organisation for Economic Cooperation and Development, OECD Factbook 2013.

${ }^{95}$ Piketty, Capital in the Twenty-First Century, 237.

${ }^{96}$ Organisation for Economic Cooperation and Development, Growing Unequal; Organisation for Economic Cooperation and Development, OECD Factbook 2013.

${ }^{97}$ Organisation for Economic Cooperation and Development, OECD Factbook 2013.

${ }^{98}$ Organisation for Economic Cooperation and Development, Divided We Stand, 18.

${ }^{99}$ Ibid., 19.

${ }^{100}$ Ibid.

${ }^{101}$ Royal Society of New Zealand, Our Futures: Te Pae Tāwhiti: The 2013 Census and New Zealand's Changing Population (Wellington: Royal Society of New Zealand, 2014).

${ }^{102}$ Ibid., 26.

${ }^{103}$ Organisation for Economic Cooperation and Development, Divided We Stand, 19. 